\title{
Trade Barrier Elimination, Economics of Scale and Market Competition: Computable General Equilibrium Model
}

\author{
Widyastutik', Suahasil Nazara ${ }^{2}$, Rina Oktaviani ${ }^{3}$, Djamester Simarmata $^{4}$ \\ I, 3, Bogor Agricultural University, 2, 4 Universitas Indonesia \\ 'widyastutik_ipb@yahoo.com, 2suahasil.nazar@ui.edu, ${ }^{3}$ rina.oktaviani@ipb.ac.id, \\ ${ }^{4}$ djamester.simarmata@ui.edu
}

\begin{abstract}
The ASEAN and its dialogue partner countries agreed to reduce trade barriers in the services sector, one of which is sea transport services. The purpose of this study is to estimate the equivalent tax of non-tariff barriers in the sea transport services. Besides that, this study is going to analyze the economic impacts of the regulatory barriers elimination in the sea transport services of ASEAN and its dialogue partner countries. Using the gravity model, it can be identified that trade barriers of sea transport services sector of ASEAN and dialogue partner countries are still relatively high. Additionally, by adopting IC-IRTS model in Global CGE Model (GTAP), the simulation results show consistent results with the theory of pro-competitive effects. The greater gain from trade is obtained in the CGE model assuming IC-IRTS compared to PC-CRTS. China gains a greater benefit that is indicated by the highest increase in welfare and GDP followed by Japan and Australia.
\end{abstract}

Keywords: trade barrier, economics of scale, market competition, gravity model

\begin{abstract}
Abstrak
Negara anggota ASEAN dan mitra dialognya telah sepakat untuk menurunkan hambatan perdagangan pada sector jasa, salah satunya pada jasa transportasi laut. Tujuan dari penelitian ini ialah untuk melakukan estimasi pajak ekuivalen dari hambata non-tarif pada jasa transportasi laut. Selain itu, penelitian ini akan menganalisis dampak ekonomi dari peraturan penghilangan hambatan pada jasa transportasi laut di negara ASEAN dan mitra dialognya. Berdasarkan model gravitasi, dapat diidentifikasi bahwa hambatan perdagangan pada sektor jasa transportasi lau antara negara ASEAN dengan mitra dialognya masih relatif tinggi. Selanjutnya, dengan mengadopsi model IC-IRTS pada model CGE Global (GTAP), hasil simulasi menunjukkan konsistensiantara hasil dengan teori propersaingan. Manfaat perdagangan terbesar pada model CGE lebih besar dengan asumsi IC-IRTS dibandingkan dengan PC-CRTS. Cina mendapatkan manfaat terbesar dari perdagangan ini, hal ini diindikasikan dengan peningkatkan kesejahteraan dan PDB, yang kemudian diikuti dengan Jepang dan Australia.
\end{abstract}

Kata Kunci: hambatan perdagangan, skala ekonomi, persaingan pasar, model gravitasi

Received: April 17, 2017; Revised: May 30, 2017; Approved: June 15, 2017 
Trade Barrier Elimination, Economics of Scale, and...

Widyastutik, Suahasil Nazara, Rina Oktaviani, Djamester Simarmata

\section{INTRODUCTION}

The characteristics of the services sector trade are different from trade in goods. For instance, the services sector is not produced and stored for later consumption. In addition to that, production and consumption are carried out simultaneously (Stern and Hoekman, 1988). Some services sectors are tangible such as restaurant services. However, most of the services sector are intangible and do not subject to tariffs. Consequently, there are many barriers in the form of restrictions in services sector trade when interaction happened between producers and consumers, in comparison to tariff barriers that commonly occur in trade in goods'. Barriers to trade in services are implemented by the government through regulation (Kalirajan, 2000). Sheperd and Marrel (2009) stated that it is very difficult to quantify the impacts of policy on trade in services. The size of the ad valorem tariffs that are transparent in goods market is very rarely found in the services sector. Therefore, alernative measures have been developed to address the issue. Sheperd and Marrel (2009) used the trade cost approach to calculate the restriction index in the service sector. High regulatory barriers reflect restriction index itself.

Regulation in the services sector is expected to reduce the asymmetric information. This protection needs to be done in order to deal with the political demands of developed countries to undertake liberalization in the services sector. Inappropriate regulation will be easily intervened by political decisions. The regulation becomes obstacle because it increases transaction costs, and hence it is ultimately charged to the consumer in the form of higher prices of services. Hertel et.al. (1999) stated in one of the models that excessive regulation contributes to a very high increase in costs (cost escalating). Another argument states that excessive regulation is equivalent to tax that will increase economic rents (Dee, et.al. 2003).

The reduction of trade barriers to the provision of services among ASEAN countries conducted through the mechanisms, which are regulated in the ASEAN Framework Agreement on Services (AFAS), signed by the ASEAN Economic Ministers

\footnotetext{
${ }^{1}$ Hoekman and Braga (1997) distinguished types of barriers: (1) quotas, local content, and prohibitions; (2) pricebased instruments; (3) standards, licensing, and procurement; and (4) discriminatory access to distribution networks. Hoekman (2011) classified types of barriers : (1) Market Access (MA), and (2) National Treatment (NT), then applied differently to 4 modes of supply in services (a) cross-border trade, (b) consumption abroad, (c) commercial presence, and (d) presence of natural persons. Deadorf and Stern (2004) distinguished types of barriers: (1) discriminatory on entry/establishment and operations (2) non-discriminatory on entry/establishment and operations. The barriers applied to domestic and foreign service providers.
} 
on 15 December 1995 in Bangkok, Thailand. To follow up the agreements, the Coordinating Committee on Services (CCS) has been established to manage services liberalization negotiations within the framework of AFAS which includes eight sectors ${ }^{2}$. As an illustration, trade in services accounts for $1 / 4$ of ASEAN trade. This sector is very important in facilitating trade in goods and Foreign Direct Investment. Growth of exports of services by ASEAN averaged 14 percent per annum. Growth of imports of services averaged II percent per annum. Meanwhile, The ASEAN total export and import of services with the world generally increased over the period 2005 to $201 \mathrm{I}$ with a slight reduction in 2009 , it was partly due to a spill-over effect of the global financial crisis in 2008. For both exports and imports, the main contributors were transportation, business services, and travel, which comprised over 80 percent of the total in both cases (ASEAN Secretariat, 20II).

Transport services sector, especially sea transport has an important role in the ASEAN trade. This is mainy due to the fact that the ASEAN region consists of vital sea lanes, destinations and transit points for world trade carried by ships. For example, 25 percent of the world's oil trade and 2,500 LNG/LPG tankers pass through this region every year. The prosperity of ASEAN Member Countries greatly depends on the efficiency, viability and safety of the shipping, port facilities and sea trade routes. Nowadays, Southeast Asia is taking advantage of its strategic location being at the sea cross roads by improving the efficiency of its ports and shipping services (www.aseansec.org).

Not only at the level of ASEAN, in 2012, a free trade agreement involving the ASEAN, China, South Korea, Japan, Australia, New Zealand and India were concluded (The Regional Comprehensive Economic Partnership) . The Free trade agreement was agreed on the final day of the Summit of the $21^{\text {st }}$ ASEAN in Phnom Penh, $15-20$ November 2012. This agreement is called the Regional Comprehensive Economic Partnership. In association with the implementation of the ASEAN-China FTA in services, China has submitted a request to liberalize Indonesia's 10 service sectors including sea transports. Similiarly, Indonesia also includes the sea transport as the base offer for the sectors included in the first commitment of the ASEAN-China FTA in services. Meanwhile, ASEAN and Korea have agreed to use the commitments in the

\footnotetext{
${ }^{2}$ The eight sectors are air and sea transport, business, construction, telecommunications, tourism, financial, health, and logistics services
} 
Trade Barrier Elimination, Economics of Scale, and...

Widyastutik, Suahasil Nazara, Rina Oktaviani, Djamester Simarmata

internal environment of ASEAN (AFAS 4 Plus-Minus) as a base of liberalization of the AKFTA services sector.

Figure I. Total ASEAN Exports and Import of Services with The World

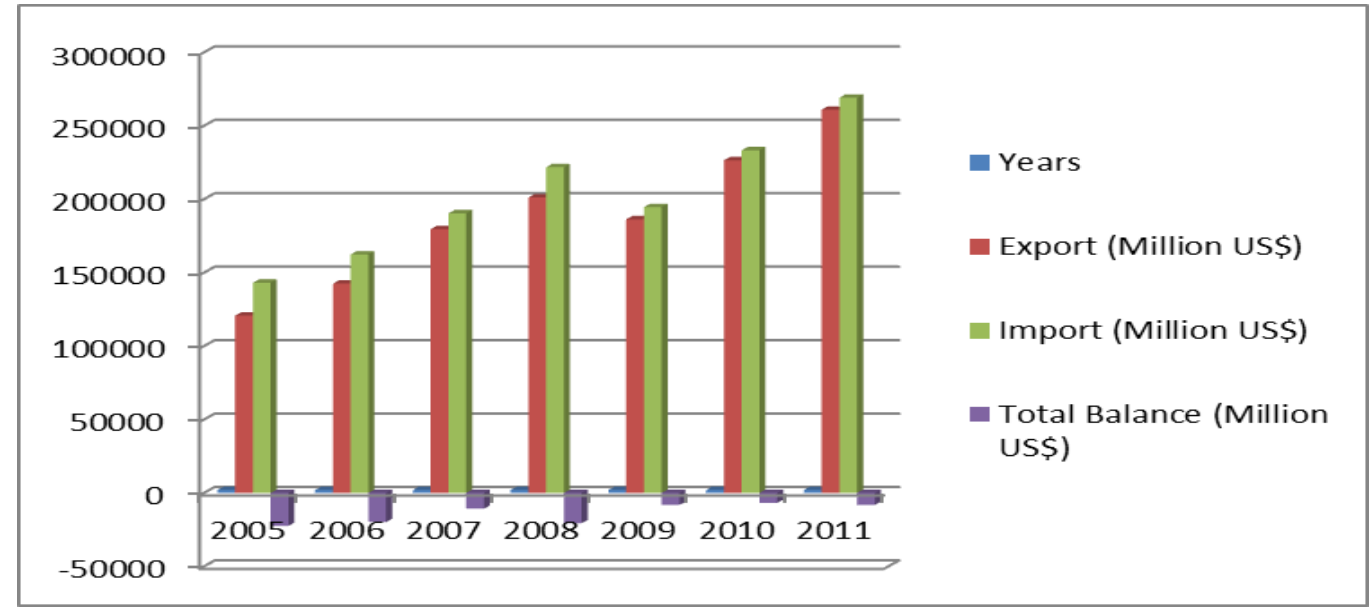

Source: ASEAN Secretariat, 2014

In line with the framework of AFAS, in order to improve trade performance in the transport sector particularly sea transport, the government has to conduct a review of all existing laws and policies. The question is not about whether there is a regulation, but rather on what kind of regulation is more appropriate and at what level. An appropriate regulation can improve the well-being through the allocation of resources to obtain the outcomes desired by the public. Otherwise, inappropriate regulation could reduce economic welfare of the injured party. Inappropriate regulation can increase the costs burdened by consumers in the form of higher prices. This paper aims to answer two questions: first, how high the regulatory barriers on Indonesian sea transport services trade in the scope of ASEAN 4 and China, Korea, Japan, Australia, New Zealand and India are and vice versa. In this paper, the regulation which is NTBs are estimated by the quantity based measures. Jager and Lanjouw (1977) stated argument that the quantity-based measures tend to be chosen rather than price-based measures because the measurements explain what we want to know about the effects of NTBs and how many NTBs reduce trade. In general, the quantity based measures approach uses gravity models. The second question, what are economic impacts of the elimination of regulatory barriers on the trade of sea transport in the scope of ASEAN 5 and China, South Korea, Japan, Australia, New Zealand and India? The method of analysis which is used to answer the second question is CGE model. The consideration of the use of CGE models in this study is in 
line with the thinking that in the future the service sector will lead to the free market, which is similiar to goods markets. Therefore, the interaction among economic actors becomes complex and difficult to be understood with a partial equilibrium model, so the use of CGE is considered to be more appropriate. In addition, the general equilibrium approach is believed to be better in analyzing intersectoral linkages, well as macroeconomic conditions. Moreover, it is also suitable for analyzing issues on the foreign trade policy as stated by De Melo (1988) and Yeah et.al. (1994).

Historically, the characteristics of service industry consist a mix of "network externalities" (such as telecommunications, finance, and transport), full of regulation (such as communication, insurance, professional services), and also the mix of both either naturally or because of policy barriers to entry. In the case of the services sector, there is a margin sector which facilitate transactions among agents such as transportation, communication, distribution (Deardorff, 200I). It implies the existence of market power through either an oligopoly, monopoly,monopsony, or oligopsony. Market forces will drive the price difference between companies and consumers, between savers and investors and the economic agents that are heavily relied on network communications and transportation. The GTAP model is modified by changing the assumption of PC-CRTS with IC-IRTS which refers to the study by Francois (1998). IC-IRTS in the GTAP model have been used by Pannenungi (2004) in the case of the ASEAN free trade area with China to accommodate the greater benefits that are sometimes not realized as a result of free trade within the trading block or multilateral tradeThe contribution of this paper is to quantify trade barriers in the sea transport of Indonesia with ASEAN countries and dialog partners. This case is still rarely done by other researchers. Additionally, It is expected to be useful as the basis for policy makers. More importantly, this paper accommodates IC-IRTS in the GTAP model in accordance with the characteristics of the transport services sector, which represents a mix of network externalities and full of regulation. Services sector, such as transport services, communication, finance. distribution, and business services have significant roles on Global Value Chain (GVC). The services sector stands as the important part in production process and sales. In the GVC related approach, it can be seen that the production stages were levied with Value 
Trade Barrier Elimination, Economics of Scale, and...

Widyastutik, Suahasil Nazara, Rina Oktaviani, Djamester Simarmata

Added tax (VAT). The problems of VAT in GVC has been considerd as an important and timely topic.

The paper is organized as follows. In the following section, this paper provides the previous quantitative studies about different methods used to estimate barriers to trade in services and the impacts of the regulatory barriers elimination on the macro and sectoral economic performance. Subsequently, the current condition of ASEAN trade in services and introduction of commitment of ASEAN member and Indonesia regulation on the sea transport are presented in the next section. Then, the following section illustrates research methodologies, i.e. gravity model and the CGE model with assumption of imperfect competition and improved economies of scale. The last section of the paper shows the results and followed by a summary and conclusion for policy-making purposes.

Some studies have estimated regulatory barriers in the services sector and analyzed the continued impact using econometric models and general equilibrium models. However, the estimation of regulatory barriers on the trade in ASEAN 5 sea transport and other FTA partners using gravity models has never been done. Moreover, there is no CGE model application that accommodates the increasing returns to scale and imperfect competition market (IC-IRTS) in the ASEAN 5 sea transport and FTA partners until now. The contributions of this paper are (I) The equivalent tariff estimation of NTBs in sea transport ASEAN 5 and other FTA partners used as the GTAP update, (2) The accommodation of increasing returns to scale and imperfect competition market (IC-IRTS). Additionally, the author also makes adjustments in the GTAP model derived from the $3^{\text {th }}$ version used by Francois $(1998)$ to be implemented into the $8^{\text {th }}$ version of GTAP model (with the aggregation of countries and sectors that are more in accordance with the purposes of the study).

\section{METHOD}

Gravity model first developed by Tinbergen (1962) that based on Isard (1954). Several studies use gravity models to estimate the tariff equivalent of NTBs in the services sector. One of the benefits is this model works well when bilateral trade regressed on GDP. According to Rose (2002) standard gravity model only includes natural logarithm of income and distance variable. The size of the market or the 
economy measured by GDP, population, or GDP per capita. Besides the economic size and the distance, there are some possible factors that affect trade such as cultural phenomena (e.g, whether the countries share a common languages), similiar geography (e.g., whether none, one or both are landlock), and the historical nature of the relationship between countries (e.g., whether colonized the other one) included in the model (Rose, 2002; Winchester, 2008).

This research also uses FTA dummy variable to capture the effect of the FTA on membership imports in the sea services sector. Based on literature, gravity model application for trade of goods includes these variables to measure the impacts of the FTA, but it is not clear whether it is approproate for analyzing trade the services sector, since most of the cooperation agreement focuses on trade in goods rather than services. For the case of ASEAN, despite the economic integration of ASEAN region started in 2015, liberalization negotiations of services ( 8 services sector) has been started since 1995 including the transportation services sector.

Gravity models in this paper is a modification of the Rose (2002) is as follows:

$\ln X_{i j t}=\alpha+\beta_{1} \ln G D P_{i t}+\beta_{2} \ln G D P_{j t}+\beta_{3} \ln$ Dist $_{i j}+\beta_{4}$ Cont $_{i j}+\beta_{5}$ Comlang_etno $_{i j}+\beta_{6}$ Comlang_off $_{i j}$ $+\beta_{7}$ DummyFTA $_{i j t}+\varepsilon_{i j t}$

Where $\mathrm{i}$ and $\mathrm{j}$ denotes countries, $\mathrm{t}$ denotes time, and the variables are defined as:

\begin{tabular}{|c|c|c|}
\hline$X_{i j t}$ & $=$ & imports of country j from country i year $\mathrm{t}$ (mio USD) \\
\hline$G D P_{i t_{2}} G D P_{j t_{2}}$ & $=$ & GDP of country $i$ and $j$ year $t$, respectively (mio USD); \\
\hline Dist $_{i j}$ & $=$ & $\begin{array}{l}\text { Geodesic distances are calculated following the great circle } \\
\text { formula, which uses latitudes and longitudes of the most } \\
\text { important cities/agglomerations (in terms of population), the } \\
\text { data are obtained from CEPII }\end{array}$ \\
\hline Cont $_{i j}$ & & a binary variable which is unity if $i$ and $j$ share a land border \\
\hline Comlang_of $f_{i j}$ & $=$ & $\begin{array}{l}\text { a binary variable which is unity if } i \text { and } j \text { share a common } \\
\text { official languageby least } 20 \text { percent of the population in both } \\
\text { countries }\end{array}$ \\
\hline
\end{tabular}

Comlang_etno $_{i j}=\mathrm{a}$ binary variable which is unity if $\mathrm{i}$ and $\mathrm{j}$ have a language is spoken by least 9 percent of the population in both countries

DummyFTA $A_{i j t}=\mathrm{a}$ binary variable which is unity if $\mathrm{i}$ and $\mathrm{j}$ both belong to 
Trade Barrier Elimination, Economics of Scale, and...

Widyastutik, Suahasil Nazara, Rina Oktaviani, Djamester Simarmata

regional trade agreement $\mathrm{k}$,

In the gravity model of sea transport services imports, the high GDP of importing countries indicate the high level of demand for sea transport services (which are produced by domestic and imported), while the high GDP exporting countries is positively related to the ability to export more services. In this study, the size of the economy on the equation of sea services import is proxied by GDP of importers and exporters. The distance is the distance of geography. The distance between the exporters and importers has a negative impact on trade in goods, but the empirical results on the literature are ambiguous for the services sector case (Walsh, 2006; Callaghan and Uprasen, 2008). Some researches indicate that the services sector is relatively little affected by distance rather than manufactured and agriculture goods because of its intangible characteristics.

Based on the equation (I), to obtain the tariff equivalent of NTBs subject to two constraints, namely:

$\sum_{i} \varepsilon_{i j}=0$ and $\sum_{i} \Sigma_{j} \varepsilon_{i j}=0$

According to Anderson and Wincoop (200I), Park (2002), Callaghan and Uprasen (2008), the residual $\varepsilon_{i j}$ is defined as the log of actual import from exporter $\mathrm{i}$ to importer $\mathrm{j}$ minus log of potential import of gravity model prediction. After all the parameters are estimated, potential trade flows can be obtained by substituting all data into the estimated gravity equation. The fitted trade flows from gravity equation is specified as a potential trade flows. Based on residual approach, the difference between actual and potential trade flows indicates tariff equivalent of NTBs normalized by freetrade benchmarks.

$\ln \left(\frac{x_{j}^{a}}{x_{j}^{p}}\right)-\ln \left(\frac{x_{b}^{a}}{x_{b}^{p}}\right)=-\sigma \ln t_{j}$

$a, p$, and $b$ are the actual, potential and benchmarks. Based on the equation (3) it can be solved $t_{j}$ namely:

$t_{j}=\exp \left\{\ln \left(\frac{x_{j}^{a}}{x_{j}^{p}}\right)-\ln \left(\frac{x_{b}^{a}}{x_{b}^{p}}\right) \quad\right\}^{\frac{1}{\sigma}}=\frac{\left(x_{j}^{a} / x_{j}^{p}\right)}{\left(x_{b}^{a} / x_{b}^{p}\right)}$

$t_{j}$ is the power of tariff equivalent of NTBs. Tariff equivalent of NTBs importer $\mathrm{j},\left(t_{j}-I\right)$ obtains: 


$$
\left(t_{j}-\mathrm{I}\right)=\frac{\left(x_{j}^{a} / x_{j}^{p}\right)}{\left(x_{b}^{a} / x_{b}^{p}\right)}-\mathrm{I}
$$

The type of data used in the gravity model is secondary data. This panel data combines time series and cross section data. Time series data used is the import of sea transportand GDP in 200I, 2004, and 2007. Cross section data consist of five ASEAN countries covering imports of Sea transport in Indonesia, Malaysia, the Philippines, Thailand and Singapore and ASEAN partner countries, namely China, Republic of Korea, Japan, Australia, New Zealand and India and vice versa. The services sector in these five countries has the highest contribution to GDP. Thus these five ASEAN countries and six countries of ASEAN partners in this study are considered as a major trade pact because it has I/3 of world GDP and 3.5 billion people.

GTAP does not accommodate the specific barriers in the services sector. Regulatory barriers associated as tariff equivalent of NTBs will be used as the update rate in the GTAP (Malcolm, 1998). Transportation services sector is made up of a network which is subject to monopoly/oligopoly (Matto, et.al, 2008), so this paper modifies in the GTAP model by changing assumptions PC-CRTs with IC-IRTS which refers to the study of Francois (1998). Next section will simulate and analyze the economic impact of the elimination of barriers to trade regulations in the sea services sector.

This study modifies the GTAP model assumptions to capture the behavior of the transportation services sector due to government intervention. As a simplification, in measuring the elasticity of demand (DELAST), Francois (1998) used non-nested Armington assumption that import-competing goods can directly compete with imported goods from each country. In IRTS, net scale is simply as SCALE = CDR / (I CDR). CDR data use the data used in Francois (1998) and Francois and Roland-Holst (1996) so that the output scale changes can be easily obtained by multiplying the SCALE with changes in the value added of sectors concerned. In IC implementation, equation mark up (mu) is adapted to GTAP so we get the following equation:

$(\mathrm{I} /(\mathrm{I}+\mathrm{SCALE}(\mathrm{i}, \mathrm{r}))) /(\mathrm{I}-\mathrm{CVRATIO}(\mathrm{i}, \mathrm{r}) / \operatorname{DELAST}(\mathrm{i}, \mathrm{r}))$

Based on the above equation scale of economies is directly related to the mark-up. The main elements of the markup is found on CVRATIO (i, r), which is a 
Trade Barrier Elimination, Economics of Scale, and...

Widyastutik, Suahasil Nazara, Rina Oktaviani, Djamester Simarmata

conjectural variation per number of firm- from 0 (for the PC) to I (for Monopoly) and DELAST (i, r). DELAST depends on the market share (ZETA) and Armington Domestic Demand Elasticity of Substitution (CESUBD). Francois (1998) treated markups as taxes that affect the price and quantity as below:

$$
\begin{aligned}
& \mathrm{ps}(\mathrm{i}, \mathrm{r})=\text { to }(\mathrm{i}, \mathrm{r})+\mathrm{pm}(\mathrm{i}, \mathrm{r})-\mathrm{mu}(\mathrm{i}, \mathrm{r}) \\
& \mathrm{pm}(\mathrm{i}, \mathrm{r})=\mathrm{ps}(\mathrm{i}, \mathrm{r})-\text { to }(\mathrm{i}, \mathrm{r})+\mathrm{mu}(\mathrm{i}, \mathrm{r})
\end{aligned}
$$

The price mechanism that higher than mark-ups affects output and other variables. The change from CRTS to IRTS is done by changing the SCALE $=0$ become SCALE = CDR / (I-CDR). While the change from the PC into the IC is done by changing CVRATIO from 0 to greater than 0 . Data change is done by changing GTAPDAT.HAR or Header Array file which is used for GEMPACK. The equation used to endogenized and calculate the price markups over marginal cost includes in the GTAP Technical Paper No. 14 provided in the form of a zip file and as the experiment conducted by Francois (1998), while the experiment of Elbehri and Hertel (2004) is available in IRTSPROF version. All sectors are treated as oligopolistic with scale economics, while agricultural is assumed to be perfectly competitive for purpose of this study.

There are two stages to perform the region and sector aggregation. First, we compile the aggregation-mapping file between sectors contained in the standard GTAP model with the desired sector in the research. Second, the mapping processed with DataAgg program of the $8^{\text {th }}$ version GTAP so that resulted header array files, parameters, and settings matching to the aggregation of sectors and regions desired. One contribution of this study is limited to make adjustments on the GTAP model derived from $3^{\text {rd }}$ version used by Francois (1998) to be implemented the $8^{\text {th }}$ version GTAP model (with more country and sector aggregation in accordance with the purposes of the study) and to update sea transport sector services tariffs. The value of CDR and Conjectural Variation (CV) ratio is adjusted with the aggregation of sectors and regions, referring to Francois (1998), Francois and Roland-Holst (1997), and Elbehri and Hertel (2004). The contribution of this research are: (I) The $3^{\text {rd }}$ version GTAP model used Francois (1998) is implemented in the $8^{\text {th }}$ version GTAP model, (2) the GTAP data base does not accommodate barriers in the services sector so we update the sea transport tariffs. 
In this study, excessive regulation is indicated as a tariff equivalent of NTBs that in the GTAP is equivalent with import tariffs (tms). Therefore the simulation applied in the GTAP is the elimination of regulatory cost barriers. This elimination is equivalent to the elimination of import tariffs - tms $(i, r, s)$ that is reciprocally all of regions.

\section{RESULT AND DISCUSSION}

\section{Empirical Result of Gravity Equation and The Tariff Equivalent of NTBs}

The estimation results of REM in bilateral trade flows by across country gravity equation models in the sea transport are presented in Table I. The coefficient of $R^{2}$ is 0.404 percent. This result indicates two things: (I) economic variables in the gravity equation of sea transport imports are less able to explain the pattern of trade properly, (2) the small value of $\mathrm{R}^{2}$ shows that there are non-economic variables that affects trade. This condition indicates the magnitude of the intervention on the import of sea services sector. $\mathrm{R}^{2}$ coefficient of sea transport import in this paper is smaller than the studies of Park (2002), Walsh (2006), and Callaghan and Uprasen (2008), Fontagne et al. (20ll). Considering to protect the domestic industry, the country often intervene with the implementation of the regulatory barriers policies for the services sector both in the form of barriers to market access and national treatment as well as the implementation of the Cabotage Principle. Cabotage is the principle of discriminatory policies against foreign suppliers and the protection against domestic transport services. This principle is indicated to affect market access so that the provision of sea transport by foreigners to be down. This regulatory affects the volume of transactions, number of operators, and number of labor and foreign capital ownership which will affect services exports and imports of both goods and other services.

Based on the estmationmates, GDP variable of importers and exporters, the distance, and ASEAN dummy variables significantly influence the import of the sea transport on the significance level of I percent, while Comlang_etno variable is significant at 5 percent significance level. The estimation results of gravity models on imports of sea transport show that an increase of I percent of GDP Country importers will increase imports of sea transport services amounting to 0.507 percent. On the other hand,demand size indicated by the high GDP of importers state shows the high demand for sea transport (both produced by domestic and imported). These 
Trade Barrier Elimination, Economics of Scale, and...

Widyastutik, Suahasil Nazara, Rina Oktaviani, Djamester Simarmata

results are consistent with the findings of Walsh (2006); Callaghan and Uprasen (2008); Fontagne et.al. (2009) for the case of the transportation services sector. This coefficient is lower compared with the findings of Callaghan and Uprasen (2008) for the case of "Impact of the 5th Enlargement on ASEAN" in the similiar sector, OTRAS (aggregation of water transport sector and other transport) is equal to 0.55 percent.

Table I. The Gravity Equation

\begin{tabular}{|c|c|}
\hline Dependent Variable & $\begin{array}{c}\text { Independent Variable } \\
\text { (Ln Import ) }\end{array}$ \\
\hline Constanta & $-|0.42|$ \\
\hline \multirow[t]{2}{*}{ LnGDPi } & $0.507 * * *$ \\
\hline & $(0.058)$ \\
\hline \multirow[t]{2}{*}{ LnGDPj } & $0.624 * * *$ \\
\hline & $(0.059)$ \\
\hline \multirow[t]{2}{*}{ LnDist } & $-0.455^{* * *}$ \\
\hline & $(0.168)$ \\
\hline \multirow[t]{2}{*}{ Cont } & -0.398 \\
\hline & $(0.4 \mid 6)$ \\
\hline \multirow[t]{2}{*}{ Comlang_Etno } & $0.653^{* *}$ \\
\hline & $(0.285)$ \\
\hline \multirow[t]{2}{*}{ Comlang_Off } & -0.291 \\
\hline & $(0.325)$ \\
\hline \multirow[t]{2}{*}{ DummyFTA } & $-0.562 * *$ \\
\hline & $(0.248)$ \\
\hline Observation & 330 \\
\hline Country Pairs & 110 \\
\hline Adjusted $\mathrm{R}^{2}$ & 0.391 \\
\hline $\mathrm{R}^{2}$ & 0.404 \\
\hline
\end{tabular}

** will be significant at the 5percent significance level, $* * *$
significance level Parentheses indicate the standard error.

The estimation results of gravity models on imports of sea transport services show that an increase of I percent of GDP Country of exporters will increase imports of sea transport by 0.624 percent. Mirza and Nicoletti (2004) stated that the supply of the service sector to foreign markets is closely related to the availability of inputs in 
both the domestic and foreign markets. GDP of exporters boosts the capacity for production, which will further increase the export of sea transport services. This is consistent with the characteristics of the services sector. The country that has a high GDP will produce the services product. Hayami and Godo (2005) stated that the economic activity of developed countries (advanced economies) would shift from the industrial sector to the service sector in response to high economic growth.

Distance has a negative and significant relationship at the level of I percent on the exports and imports of sea transport. This negative relationship is consistent with research of Lejour, et.al. (200I) for the case of the EU, Park (2002), Fontagne, et al. (2009) for the case of the sea transport, but has a different direction with the findings of Walsh (2006) and Fontagne et al. (20I I). Some studies show an ambiguous effect in the service sector, because the product does not physically transport services from one location to another. However, given the transport sector is the service sector that is relatively physically transport goods from one location to another, then in this model range has a negative relationship with the import of sea transport.

At least 9 percent of common language used by the two countries increase trade, as it shows an economically and statistically significant relationship. Language has been found to be significant in gravity model assessments of sea transport trade flows and this effect could be expected to be particularly strong in services, as common language should greatly facilitate many transactions. There is an evidence to suggest that a common language variable may also capture other effects such as cultural or institutional similarities between countries. This should be borne in mind when interpreting the results of the model. Instead of at least 20 percent similarity language used by residents and the border between the two countries do not significantly increase trade. Although the five ASEAN countries are still in Malaysia, but only Malaysia and Indonesia, which have a similar language. Therefore Comlang_etno is more significant than Comlang_off. Likewise for sharing the border, only Indonesia has borders with Singapore and Malaysia. The other five ASEAN members do not have borders with other FTA partner countries. Rose (2002); and Walsh (2006); Fontagne, et al. (20II) only use common languages variable that indicates the value of one if the two countries share a common (official) language and zero otherwise. Research results of Rose (2002) showed that sharing a language increase of trade by economically and 
Trade Barrier Elimination, Economics of Scale, and...

Widyastutik, Suahasil Nazara, Rina Oktaviani, Djamester Simarmata

statistically significant amounts. While studies Fontagne, et al. (20II) showed on average, a common language appears to have a positive effect on trade while, belonging to the same zone, such as ASEAN (bilsa) or Latin America (Bilac), does not favor trade between countries. Although rather counterintuitive, this result demonstrates that trade in services mainly concerns developed country pairs or pairs with at least one developed country partners. The exception is that the business services sector (obs) in Asia (well documented in the literature), which shows a positive impact of free-trade agreements on trade. Walsh study (2006) showed the dummy of common languages does not significantly increase trade in transport services sector.

DummyFTA is used to capture the effects of membership of a country in FTA cooperation in sea transport services exports equation. DummyFTA significantly and negatively affects the imports of the sea transport. Significance of FTA membership in the equation of the sea transport import because the value of transportation services is closely linked to trade in physical goods that most liberalized in ASEAN and FTA partners. Negative sign indicates that the demand for goods trade is not capable for causing "knock on effect" in import of sea transport services. The significance of dummyFTA is consistent with research of Walsh (2006) in the case of transport services for Europa Union (EU) membership, but it has different sign. The EU membership has a positive impact on trade in goods that implies the existence of "a knock-on effect" on the demand for goods transport services in the EU. The negative sign is in line with research of Uprasen and Callaghan and Uprasen (2008) for dummy CEECS in the case of air transport services.

Furthermore, the predictive model of sea transport services import equation is used to calculate regulatory barriers as tariff equivalents of NTBs. The elasticity of subsitution refers to the previous research from Francois (200I) which uses I.26 as the elasticity of the services sector trade. Free trade benchmark is the import of Australia from Singapore. Table 2 shows the tariff equivalents of NTBs in equation of five ASEAN transport services sectors imports and other FTA partners.

The Tariff equivalents of NTBs in sea transport imports between Australia and Singapore have the lowest value. This is consistent with Wong and Hollweg (2015) asSingapore continued to have the most efficient regulations and procedures in the logistic sectors (six primary categories of restrictions on customs, investment, 
movement of people, maritime transport, aviation transport and road transport) relative to its regional peers in 2013. Malaysia, China, Indonesia, and the Philippine were the most restrictive economies for logistic services in this region. Relatively, Singapore and Australia were the most open economyes for trade in logistic services, along with Japan and New Zealand for both domestic and total indices. This is supported by the real conditions in which the majority of intra-ASEAN trade both exports and imports of non-bulk (container) for the purpose of non-ASEAN countries including Australia transshipped to the Singapore Port. For the case of Indonesia, the port of Tanjung Priok is only able to serve 50 percent and Tanjung Perak is only able to serve 34 percent of the total container movement in Indonesia. This condition causes most of the containers must do transshipment to Singapore and Malaysia port (the port of Port Klang and Tanjung Palepas) including containers for intra-ASEAN trade. However, some direct ship cells can be served for shipping to East Asia and China.

Table 2. Tariff Equivalents on NTBs of ASEAN 5 Sea Transport and its Dialog Partners

\begin{tabular}{|c|c|c|c|c|c|c|c|c|c|c|c|}
\hline \multirow[b]{2}{*}{ Importer } & \multicolumn{11}{|c|}{ Exporter } \\
\hline & Idn & Mys & $\mathrm{Phl}$ & Tha & Sgp & Chn & Jpg & Kor & Aus & $\mathrm{Nzl}$ & Ind \\
\hline Idn & - & $|0.5|$ & 12.33 & 6.93 & 6.96 & 9.08 & 8.03 & 7.28 & 7.64 & 8.56 & 7.65 \\
\hline Mys & 9.85 & - & 7.81 & 5.46 & 8.11 & 5.75 & 5.43 & 5.75 & 4.48 & 5.85 & 5.07 \\
\hline $\mathrm{Phl}$ & 11.42 & 8.38 & - & 8.62 & 8.66 & 9.64 & 8.82 & 9.65 & 12.59 & 12.88 & $|2.0|$ \\
\hline Tha & 2.74 & 5.49 & 10.55 & - & 2.83 & 6.52 & 4.58 & 4.69 & 6.00 & 6.33 & 8.73 \\
\hline Sgp & 10.11 & 9.02 & 12.93 & 2.47 & - & 9.74 & 2.30 & 3.94 & 8.72 & 7.48 & 4.25 \\
\hline Chn & 10.88 & 11.19 & 12.92 & 10.44 & 13.27 & - & 9.59 & 6.96 & 9.86 & 11.34 & 17.79 \\
\hline Jpg & $|2.6|$ & 8.46 & 15.39 & 6.12 & 4.95 & 10.31 & - & 8.25 & II.24 & 10.51 & 5.71 \\
\hline Kor & 8.68 & 9.15 & 17.67 & 6.29 & 5.73 & 12.17 & 7.99 & - & 7.08 & 6.86 & 8.94 \\
\hline Aust & 1.10 & 5.44 & 20.49 & 7.73 & 0.00 & 6.14 & 7.36 & $6.4 I$ & - & 15.49 & 9.85 \\
\hline $\mathrm{Nzl}$ & 9.57 & 8.50 & 17.35 & 6.79 & 8.28 & 11.18 & 8.63 & 9.71 & 14.54 & - & 11.24 \\
\hline Ind & 11.22 & 6.58 & 16.25 & 6.92 & 4.74 & 17.30 & 3.37 & 4.98 & II.7I & 10.34 & - \\
\hline
\end{tabular}

Source: Author's Calculation

The tariff equivalent average of NTBs in this paper is from 0 up to 20.49 percent. A tariff equivalent of NTBs of Australia import from Singapore and Indonesia is relatively low but it has the highest tariff equivalent of NTBs if importing from the Philippines. This paper also demonstrates that although Singapore is a country that is 
Trade Barrier Elimination, Economics of Scale, and...

Widyastutik, Suahasil Nazara, Rina Oktaviani, Djamester Simarmata

traditionally open to trade, but it has the high tariff barriers equivalent of NTBs for imports from the Philippines and Indonesia.

The value of tariff equivalent of NTBs in this study is not much different from the findings of Park (2002). Study of Park (2002) using data from the $5^{\text {th }}$ version GTAP in the transport services sector showed that Singapore also becomes the benchmark country. Tariff equivalent of NTBs in the sea transport for some countries are Indonesia at 22.52 percent, Malaysia and Thailand amounted to 15.72 percent, the Philippines at 17.43 percent, China amounted to 28.44 percent, Australia at 16.45 percent, New Zealand at 6.15 percent, Japan at 18.17 percent, Korea amounted to 8.73 percent, and India at 32.93 percent.

However the study results of Walsh (2006) using the service imports sourced from the OECD's statistics on international trade in services showed the relatively higher average of import tariff. Indonesia has an average import tariff equivalent of I 24.8 percent, Malaysia amounted to II9.6 percent, Philippines amounted to 122.7 percent, Singapore at 83.5 percent, Thailand amounted to 120.9 percent, New Zealand amounted to 82.8 percent, Australia amounted to 56.3 percent, China amounted to I 2 I.3 percent, and India amounted to II 3.7 percent. The tariff equivalent of NTBs of Japan is 0. Callaghan and Uprasen (2008) study showed that the tariff equivalent of NTBs of OTRAS (other transport and water transport) sector is lower when the EU15 as an importer than the CEECs-10 as an importer. Tariff equivalent of NTBs EU-I5 as importers is amounted to 6.72 percent and the CEECs-10 as the importer is amounted to 45.80 .

\section{The Simulation Result of CGE Model}

The impact of elimination tariff equivalent of NTBs of maritime services on selected macroeconomic variables is presented in Table 3. More specifically, Table 3 shows the impact of the tariff equivalent of NTBs elimination of sea transport services between ASEAN 5 and its dialogue partners and reciprocally. Changes in the assumptions of the PC-CRTS to IC-IRTS generate sensitivity of gains from trade in the form of the value changes effect in GDP and EV that increase. Referring to Pannenungi (2004), there is an indication that intra-industry trade increases with the IC-IRTS assumption, although he was not able to quantify the magnitude of the intra-industry trade. 
Assuming IC-IRTS and PC-CRTS, China has indicators of macro variables (Equivalent Variation, Trade Balance, and real GDP) that are higher compared with other countries involved in the trade. The high coefficient of the macro indicators are caused by impact of the higher tariffs elimination imposed by China to trading partners. Based on estimates on the average value of equivalent rates of NTBs, China occupies highest position compared to other countries. However, assuming the IC-IRTS, China's macroeconomic indicator variable is higher than the PC-CRTS. These findings support research by Pannenungi (2004) with the assumption that the IC-IRTS, China will gain the greater gain from trade. Pannenungi (2004) stated that China's economic potency will be realized when taking into account the IC-IRTS. Tariffs elimination simulation on Chinese sea transportation service sector provides incentives for sea transport sector itself and other sectors to increase output.

Table 3. Impact on Selected Macroeconomic Variables

\begin{tabular}{|c|c|c|c|c|c|c|c|c|}
\hline \multirow[b]{2}{*}{ Reg } & \multicolumn{2}{|c|}{ Welfare (Million USD) } & \multicolumn{2}{|c|}{ GDP (Percent) } & \multicolumn{2}{|c|}{$\begin{array}{l}\text { Trade Balance } \\
\text { (Million USD) }\end{array}$} & \multicolumn{2}{|c|}{$\begin{array}{c}\text { Term of Trade } \\
\text { (Percent) }\end{array}$} \\
\hline & IC-IRTS & PC-CRTS & IC-IRTS & PC-CRTS & IC-IRTS & PC-CRTS & IC-IRTS & PC-CRTS \\
\hline Idn & 14.05888 & 3.10183 & 0.00355 & 0.00018 & -0.20275 & -0.48281 & -0.00170 & 0.00207 \\
\hline Mys & 6.77311 & 4.90851 & 0.00129 & -0.00049 & 0.65849 & -4.52202 & 0.00110 & 0.00377 \\
\hline $\mathrm{Phl}$ & 1.55676 & 2.53717 & 0.00077 & 0.00037 & 0.09524 & -0.89774 & 0.00057 & 0.00295 \\
\hline Tha & 0.51646 & 7.48587 & 0.00066 & 0.00096 & -0.72500 & -3.01887 & -0.00074 & 0.00353 \\
\hline Sgp & 7.15410 & 3.44161 & 0.00233 & 0.00209 & 0.54015 & -4.90157 & -0.00002 & -0.00237 \\
\hline Chn & 251.92009 & 19.09146 & 0.00864 & 0.00023 & 29.09468 & 2.70749 & -0.00534 & 0.00087 \\
\hline Jpn & 36.60807 & -9.17088 & 0.00449 & 0.00004 & -11.54859 & $-39.78 \mid 48$ & 0.00163 & -0.00090 \\
\hline Kor & $12.79 \mid 25$ & -31.17717 & 0.00116 & 0.00073 & -2.89026 & -16.54738 & 0.00003 & -0.00857 \\
\hline Aus & 23.76920 & 7.41679 & 0.00272 & 0.00030 & -1.49090 & -7.59611 & 0.00096 & 0.00258 \\
\hline $\mathrm{Nzl}$ & 0.73569 & 3.41380 & 0.00036 & 0.00062 & -0.63278 & -3.47855 & 0.00064 & 0.00756 \\
\hline Ind & -2.02328 & $26.45|5|$ & 0.00010 & 0.00059 & -12.59826 & -10.28294 & -0.00106 & 0.00650 \\
\hline ROW & | 44.60847 & -26.75013 & 0.00016 & -0.00007 & $-0.0000 \mathrm{I}$ & 88.80190 & 0.00048 & -0.00003 \\
\hline
\end{tabular}

Source: Author's Estimation

Based on data from $8^{\text {th }}$ version of GTAP, approximately 83.92 percent of international transport of Chinese exports uses sea transport services, 14.17 percent by air transport services, and the rest use other transportation. This condition suggests that sea transport is an important input in the production process in China. Therefore the regulatory reforms that reduce the trade cost in the sea transport services are not only improve the allocation of resources through specialization with 
Trade Barrier Elimination, Economics of Scale, and...

Widyastutik, Suahasil Nazara, Rina Oktaviani, Djamester Simarmata

comparative advantages, but also significantly contributes as a "knock on effect" in the economy. Research conducted Limao and Venables (2000) showed that the increase in the quality of infrastructure can reduce transportation costs by 40 percent for the country surrounded by sea and 60 percent for landlocked countries. Efficiency in port reduces shipping costs more than 12 percent, equivalent to a distance of 5000 Miles. This is evidenced by China. The transportation sector becomes supporting infrastructure in international trade since 1990. Regulatory reform affects the production of the transportation services sector. Development of the world's cargo is currently around 80 percent and it is mostly transported by ship. China is able to take advantage of these conditions. China port capacity increased from 300 million tons in 1985 to 2.9 billion tons in 2005. In 201 I the Port of Shanghai (China) ranked first with traffic cargo loading as many as 29 million Twenty Equivalent Units (TEUs) and NingboZhoushan (China) ranked second. Since 2002, China has been reforming its economy towards the third stage of the socialist economy. This reform is a form of a reduction in control on the market and prices for more products, and hence most products are determined by market. The scope of enhanced performance is the administration thereby providing good services to the market. As the impact at the end of 2007, 64.3 percent of China's products are market-determined, whereas in 1992 the government determines almost 90 percent of China's products. Because of the trade openness, the percentage of China's trade to GDP in 1999 amounted to 37.97 percent and rose sharply in 2008 amounted to 62.09 percent (World Development Indicators, 2010). A policy called "open policy" (kaifang) is a policy that is very different from the policy of Mao Zedong.

Pannenungi (2004) stated, with IC-IRTS assumption that China's gain is smaller than ASEAN in the ACFTA. Using data from $8^{\text {th }}$ version of GTAP, the question of why the Chinese are interested in the benefits of ACFTA although relatively smaller compared with ASEAN has been missed. Economic factors remain a consideration for China why are interested in ACFTA. China look forward to the future that ASEAN has the endowments for production (natural resources and cheap labor), additionally the market is considered as the entry point to trade with other countries. Assuming ICIRTS, the regulatory reform in the sector of sea transport services benefit China more than in the five ASEAN countries as well as other ASEAN trading partners. China has 
predicted that Indonesia together with Philippines and Japan as an island nation located in the Asia Pacific region has a key role in the growth in this region (Asian Development Bank and World Bank, 2000). This economic potency has strategic value, in line with the shifting center of world economic activity since the end of the $20^{\text {th }}$ century from the Atlantic to Asia-Pacific. Trade of Asia-Pacific countries nearly 70 percent of total world trade and more than 75 percent of traded goods transported by sea, especially through the Malacca Strait, Lombok Strait, Makassar Strait, and other Indonesia sea. ASEAN countries, especially Indonesia is the entrance to trade with Asia-Pacific countries and others.

Assuming IC-IRTS, respectively Japan, Australia and Indonesia is the next country after China, which has a high welfare with regulatory reform in the sea transport services sector. In terms of the increase in real GDP, Indonesia ranked second after China followed by Australia. Other ASEAN countries that have high welfare and real GDP are Singapore and Malaysia. Increased welfare and the country's real GDP show that sensitivity of gain is greater when the regulatory reform in the sea transport services sector with the IC-IRTS assumption. Alejandro et al. (2010) showed that the main ports in Southeast Asia (except Indonesia's Tanjung Priok port) are Singapura, Klang and Tanjung Palepas in Malaysia. IC-IRTS assumptions encourage monopolists to lead to a competitive price so that output expands higher than the PCCRTS assumptions.

The elimination of regulatory barriers in the services sector of sea transportation affects the welfare, the trade balance and terms of trade of India. The impact of the decline in welfare in India with IC-IRTS assumption is in line with research of Elbehri and Hertel (2004) for the case of the EU-Morocco FTA. EUMorocco FTA shows that the implementation of general equilibrium with oligopoly and economies of scale in the case of the EU-Morocco FTA gives adverse impact on Morocco, worsening terms of trade, reducing the output of the company in an industry dominated by economies of scale, the occurrence of trade diversion import costs which is relatively lower to non-EU suppliers, and worsening the aggregate demand for labor. Value changes in China's total trade balance showed a surplus, which is very high in the event of changes in assumptions of PC-CRTS to IC-IRTS. Assuming IC-IRTS, ASEAN countries that have a surplus balance of trade are Malaysia, Singapore, and 
Trade Barrier Elimination, Economics of Scale, and...

Widyastutik, Suahasil Nazara, Rina Oktaviani, Djamester Simarmata

Philippines. On the oter hand, the balance of trade of Indonesia, Thailand and other countries are deficit. The negative value changes of the trade balance in several countries including Indonesia show that strength of Indonesian export supply has not been able to respond an opportunities of trade barriers elimination. Elimination policy of trade barriers in the form of duties is more potential to increase the growth rate of imports than exports. Assuming IC-IRTS, in the case of Indonesia's trade balance only sector of sea transport services, textile and wearing apparel, trade, and utility construction has a positive trade balance. Referring to the term used by Pannenungi (2004), these three sectors are winner sectors in the event of regulatory barriers elimination of sea transport services sector, while other sectors are losers sectors.

Assuming IC-IRTS, Indonesia, Singapore, Thailand, India and even China have decreased the TOT. When the trade liberalization is imposed, the effect of the economics of scale and market competition is the increase of imports from foreign services providers. These conditions encourage the monopolist to lead to a competitive price. Under more complex specifications of market forces and industry structure, pro-competitive effects relate to increased economies of scale and decreased cost. This condition explains that export prices decrease relatively to import prices in IC-IRTS condition. The largest decline of terms of trade occurs in China. This condition shows that pro-competitive effects related to increased economies of scale and cost-down in China is greater than in other countries.

\section{Impacts on The Structure of Production}

Assuming IC-IRTS, the elimination of regulatory barriers in sectors of sea transport services only provides incentives increased output in the four sectors in Indonesia. In addition to sea transport sector ( 0.18282 percent), textiles and apparel ( 0.3748 I percent), utility_construction $(0.00039$ percent), as well as trade $(0.00448$ percent), other sectors experience a contraction. The sectors that experienced the highest output contraction are heavy-manufacture (petroleum, coal product; chemical, rubber, plastic products; mineral product; ferrous metal; metals; metal product; electronic equipment; machinery and equipment. Import of heavy-manufacturing of Indonesia from ASEAN countries and dialogue partners increase. The threats of imports are not able to provide incentives for the monopolist in Indonesia to boost 
output. Pro-competitive effects do not occur in heavy-manufacturing sector and other sector contracted.

These sectors are food processing, utility construction, other transport and other services. This condition is different from other ASEAN countries. Assuming ICIRTS, the output in almost all sectors in Malaysia has expanded. The sectors that have expanded in Malaysia are agriculture, mining, food processing, light manufacturing, heavy manufacturing, sea transport, air transport, other transport, communication, and other services. The rest experiences contraction. The number of sectors that have been experience expansion in Thailand, Singapore, and the Philippines are higher in comparison to the sectors in Indonesia. This condition shows that Indonesian sea transport sector has not been able to become a "knock on effect" for all sectors in the economy compared to other ASEAN countries.

\section{Figure 2. Trade of Intra and Extra ASEAN Services Sector}

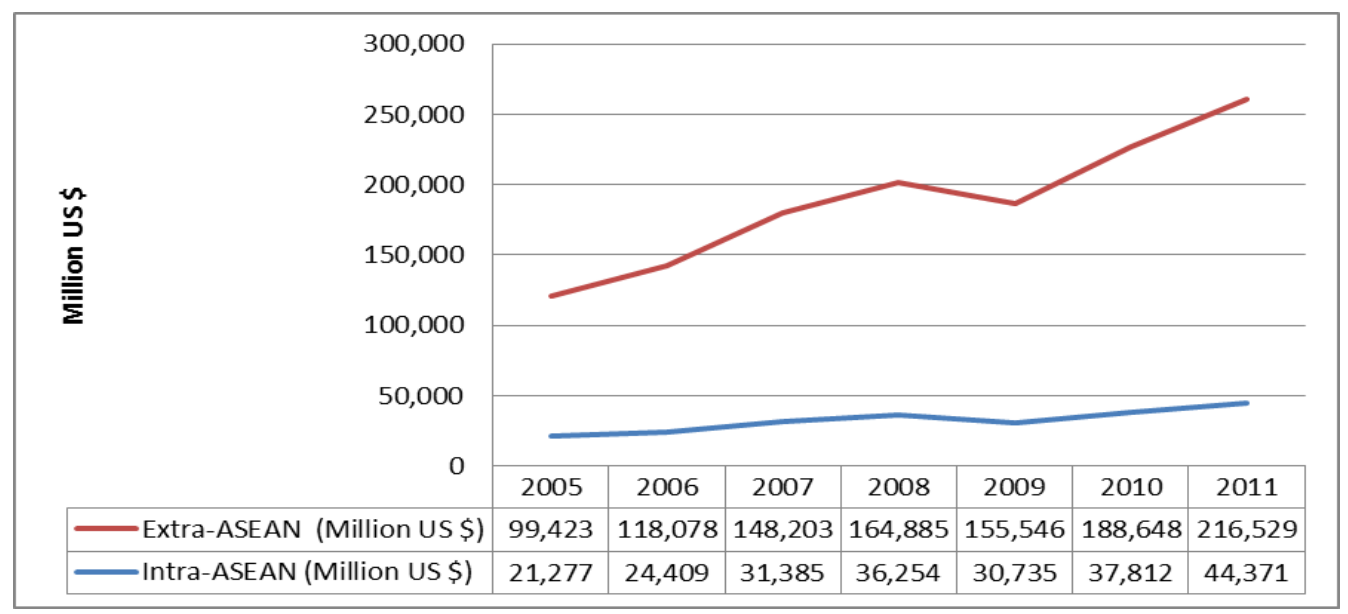

Source: ASEAN Secretariat, 2014

ASEAN trade services sector has increased both in the scope of the intra and extra ASEAN during the period 2005 to $201 \mathrm{I}$ except 2008. However extra ASEAN trade in services is more dominating than the intra ASEAN. The progress of services trade intra and extra ASEAN can be seen in Figure 2. Transportation, travel, and other business services subsectors accounted for the majority of ASEAN's service exports and imports. These three sectors comprised $85 \%$ of total service exports and $80 \%$ of imports in 2011. Exports of transportation, travel, and other business services subsectors increased in 2007 until 2008 and decreased in 2009 because of global financial crisis in 2008. Financial services and computer and information services also played a large role in ASEAN services trade. 
Trade Barrier Elimination, Economics of Scale, and...

Widyastutik, Suahasil Nazara, Rina Oktaviani, Djamester Simarmata

One of the key pillars of the AEC Blueprint is the free flow of trade in services. The AEC Blueprint focuses on five priority services sectors. They are air transport, eASEAN, health and care, tourism, and logistics services. In transport services, most ASEAN countries have taken a relatively liberal approach to many aspects of maritime regulation, but none meet the Blueprint target of allowing at least $51 \%$ foreign ownership by 2010 in all sea transport services. Shepherd and Pasadilla (2012) also find that most countries have not met the minimum foreign ownership requirement for logistics services. The AEC Blueprint target stipulates air transport services that foreign ownership limits to be raised to $70 \%$ by 2010 , for domestically established air transport services companies. Effective liberalization of trade in air transport services requires the reform of both investment laws and withholding clauses in air transport services agreements; substantial ownership by an ASEAN community of interests rather than substantial domestic ownership is thus the target for this sector.

\section{CONCLUSION}

Using residual approach of gravity models, the average tariff equivalent of NTBs in marine transportation service sector of member countries of ASEAN 5 and dialogue partners ranges from $0 \%$ to $20.49 \%$. In line with the pro-competitive effects theory of trade policy, the simulation results in this paper show the greater gain from trade obtained in CGE models assuming IC-IRTS compared to PC-CRTS. Assuming IC-IRTS, China becomes the winner indicated by the highest increase in welfare and GDP followed by Japan and Australia. In total, value changes in China's trade balance had a very high surplus when PC-CRTS assumptions are changed becomes IC-IRTS. Assuming IC-IRTS, Indonesia followed by Malaysia and Singapore are the ASEAN-5 countries that have a high level of welfare because of the elimination of barriers to trade regulations of marine transportation services. Based on the pro-competitive effects in the case of small countries, the elimination of import tariff equivalent on marine transport services sector will improve the welfare higher than the assumptions PC-CRTs. This condition shows that the impact of the elimination of barriers to trade regulations in marine transportation services sectors of Indonesia only provides incentives to increase output and export performance in the services sector of marine transportation, textile and wearing apparel, trade, and utility construction. Indonesian 
marine transport services sector has not been able to become a "knock on effect" in the economy.

Estimation result of tariff equivalents of NTBs shows that regulatory barriers in the sea transport sector of ASEAN-5 and the dialogue partner country is still high. ASEAN member countries have significant difference of commitment. To fulfill the agreement in the AEC Blueprint, some ASEAN members still must strive to achieve the targets that have been agreed. ASEAN has a variety of capacities and priorities for each of the services sector. Members of ASEAN such as Singapore are very liberal and advocated free market access. On the other hand, countries such as Indonesia, the Philippines, and Thailand have large domestic market, which tends to be protected. The success of regulatory reform in the marine transportation services sectors of ASEAN-5 and dialogue partners depends on the political will of the governments of each country to fulfill the AEC Blueprint agreement. Regulatory reform in the sea transport services sector is highly relevant to the efficiency of the regional supply chain. The efforts needed consist: Firstly, enhancing ASEAN trade facilitation and dialogue partners. The cooperation between ASEAN countries and dialogue partner is needed to overcome regulatory externalities such as differences in regulations related to the standards that will reduce the gain from trade as the international oligopoly in the trade of marine transportation services. Secondly, members of ASEAN and its dialogue partners should optimize the implementation of National Single Windows ASEAN.

Increasing the dwelling time at the port causes negative impacts to the economy, namely: First, reducing competitiveness. Delays will hamper the efforts of Indonesia to become an integrated part of the global supply chain, Second, increasing cost. Low productivity means the ship will lean time in the ports. The longer the time to lean, the higher direct operating costs and the opportunity cost. Accommodative deregulation of port and restructuring of the order of port becomes the primary consideration for improving the management of port of ASEAN countries in general and Indonesia in particular. Fair competition climate will be able to realize a modern port services and global competitiveness. Modernization of port facilities and improving the quality of service performance of port will provide multiplier effects in other sectors, so that the expectations of higher national economic growth will be achieved. 
Trade Barrier Elimination, Economics of Scale, and...

Widyastutik, Suahasil Nazara, Rina Oktaviani, Djamester Simarmata

\section{REFERENCES}

Anderson, J.E. \& E.V. Wincop. (200I). Gravity with Gravitas: A Solution to the Border Puzzle. NBER Working Paper No.8079.

Callaghan, B., A. \& U. Uprasen. (2008). Impact of the $5^{\text {th }}$ EU Enlargement on ASEAN. Euro-Asia Centre (EAC), Working Paper. Ireland: Kemmy Business School University of Limerick, Ireland.

Dee, P., K. Hanslow. \& T. Phamduc. (2003). Measuring the cost of barriers to trade in services, in Ito, T. and Krueger, A. (eds), Services Trade in the Asia-Pacific Region. NBER-East Asia Seminar on Economics, Volume II, University of Chicago Press, Chicago, pp. II-43.

De Melo, J. (1988). CGE Models for The Analysis of Trade Policy in Developing Countries. Policy Research Working Paper Series 3, The World Bank.

Elbehri, A., \& T. Hertel. (2004). A Comparative Analysis of The EU-Morocco FTA vs Multilateral Liberalization. GTAP Working Paper No.30. Revised 2006. Center for Global Trade Analysis, Purdue University.

Francois, J.F. (1998). Scale Economies and Imperfect Competition in the GTAP Model. GTAP Technical Paper No. 14.

Francois, J. (200I). The Next WTO Round: North-South Stakes in New Market Access Negotiations. Adelaide: Centre for International Economic Studies.

Francois, J.F., dan D.W. Roland-Host. (1996). Trade Policy, Scale Economies and Imperfect Competition in Applied Model. Cambridge: Cambridge University Press.

Hayami, Y \& Y. Godo. (2005). Development Economics. From the Poverty to The Wealth of Nations ( $3^{\text {rd }}$ Ed). Oxford: Oxford University Press.

Hertel, T., K. Anderson., J. Francois. \& W. Martin. (1999). Agriculture and NonAgricultural Liberalisation in the Millennium Round. Paper presented at the Global Conference on Agriculture and the New Trade Agenda from a Development Perspective: Interests and Options in the WTO 2000 Negotiations, World Bank and WTO, Geneva, I-2 October.

Isard, W. (1954). Location Theory and Trade Theory: Short-Run Analysis. Quarterly Journal of Economics, 68: 305-322.

Kalirajan, K. (2000). Restrictions on Trade in Distribution Services. Productivity Commissions Staff Research Paper. Canbera: Ausinfo. 
Lejour, A.M., R.A. de Mooij. \& R. Nahuis. (200I). EU: Enlargement: Economic Implication for Countries and Industries. CPB Document II. CPB Netherland Bureau for Economic Policy Analysis.

Limao, N. \& A.J. Venables. (1999). Infrastructure, Geographical, Disadvantage, and Transport Cost. Policy Research Working Paper. The World Bank Development Research Group Trade.

Matto, A., R.M. Stern., \& G. Zanini. (2008). A Handbook of International Trade in Services. Oxford: Oxford University Press.

Pannenungi, M.A. (2004). Model CGE dengan Skala Ekonomi yang Meningkat dan Persaingan Tidak Sempurna: Aplikasi pada Studi Kawasan Perdagangan ASEANChina (CGE Model With Increasing Economic of Scale and Incompetitive Market: Aplication in ASEAN-China Trade Are). (Unpublished Dissertation). Depok: Universitas Indonesia.

Park, S.C. (2002). Measuring Tariff Equivalent in Cross Border Trade in Services. KIEP Working Paper 02-15, Korea Institute for International Economic Policy.

Rose, A.K. (2002). Estimating Protectionism through Residuals from The Gravity Model. Working Paper. California: University of California Berkeley.

Sheperd, B. \& E.V.D. Marrel. (20I0). Trade in Services in The APEC Region: Pattern, Determinants, and Policy Implications. APEC Policy Support.

Stern, R. \& B. Hoekman. (1988). The Service Sector in Economic Structure and in International Transactions. in L. Castle and C. Findlay (eds.), Pacific Trade in Services. Sydney: Allen \& Unwin.

Tinbergen, J. (1962). Shaping the World Economy: Suggestion for an International Economic Policy. Appendix VI. New York: The Twentieth Century Fund.

Walsh, K. (2006). Trade in Services: Does Gravity Hold? A Gravity Model Approach to Estimating Barriers to Services. Institute for International Integration Studies (IIIS) Discussion Paper. No 183/October 2006.

Winchester, N. (2008). Is There Are Dirty Little Secret? Non Tariff Barriers and The Gain From Trade. Economics Discussion Papers. New Zealand: University of Otago.

Wong, M., H. \& C.H. Hollweg. (20I5). Regulatory Restrictions in Logistic Services of ASEAN+6 Economies in ASEAN and Regional Free Trade Agreements. Edited 
Trade Barrier Elimination, Economics of Scale, and...

Widyastutik, Suahasil Nazara, Rina Oktaviani, Djamester Simarmata

Christoper Findlay. Routledge-ERIA Studies in Development Economics. London: Taylor and Francis Group.

Yeah, K.L., J.F. Yanagida., \& H. Yamauchi. (1994). Evaluation of External Market Effects and Government Intervention in Malaysia Agriculture Sector: A Computable General Equilibrium Framework. Agric, Econ. I I(2-3): 237-256. 
Appendix I. Percentage Changes in Production

\begin{tabular}{|c|c|c|c|c|c|c|c|c|c|c|c|c|c|}
\hline Industry & Simulasi & Idn & Mys & $\mathrm{Phl}$ & Tha & Sgp & Chn & Jpn & Kor & Aus & $\mathrm{Nzl}$ & Ind & Row \\
\hline \multirow{2}{*}{ Agriculture } & IC-IRTS & -0.00189 & 0.00989 & -0.00085 & 0.00117 & -0.00823 & 0.01481 & 0.00056 & 0.00077 & 0.00466 & 0.00192 & -0.00089 & 0.00020 \\
\hline & PC-CRTS & -0.00023 & -0.00555 & -0.00010 & -0.00405 & -0.00513 & -0.00014 & -0.00438 & -0.00112 & -0.00474 & -0.02288 & -0.00137 & 0.00085 \\
\hline \multirow{2}{*}{ Mining } & IC-IRTS & -0.01976 & 0.03027 & -0.00814 & 0.01440 & 0.00954 & -0.03535 & 0.00508 & 0.01170 & 0.00535 & 0.00622 & 0.00496 & 0.00343 \\
\hline & PC-CRTS & -0.00173 & -0.00828 & -0.00362 & -0.00743 & -0.00753 & -0.00201 & -0.01332 & -0.00899 & -0.00332 & -0.00661 & -0.00682 & 0.00041 \\
\hline \multirow{2}{*}{ ProcFood } & IC-IRTS & -0.01104 & 0.21834 & -0.00755 & -0.00357 & -0.08080 & -0.00613 & 0.00076 & 0.00086 & 0.00274 & 0.00027 & 0.00310 & 0.00003 \\
\hline & PC-CRTS & 0.00181 & -0.00018 & -0.00243 & -0.00941 & 0.00004 & 0.00022 & -0.00137 & -0.00220 & -0.00259 & -0.02633 & -0.00134 & 0.00058 \\
\hline \multirow{2}{*}{ TextWapp } & IC-IRTS & 0.37481 & -6.40641 & -0.19529 & -0.22693 & 0.21583 & 0.37289 & -0.35058 & -0.45498 & -0.88029 & -0.14264 & -0.09383 & -0.08985 \\
\hline & PC-CRTS & -0.00948 & -0.00874 & -0.01459 & -0.02753 & -0.03763 & 0.00111 & -0.00770 & -0.00752 & -0.01125 & -0.04254 & -0.01496 & 0.00277 \\
\hline \multirow{2}{*}{ LightMnfc } & IC-IRTS & -0.01727 & 0.01964 & -0.00293 & 0.00453 & -0.00866 & -0.01713 & 0.00159 & 0.00205 & 0.00789 & 0.00383 & 0.00697 & 0.00253 \\
\hline & PC-CRTS & -0.00147 & -0.00443 & 0.00111 & -0.01059 & -0.02358 & 0.00170 & -0.00936 & -0.00677 & -0.00344 & -0.02477 & -0.00828 & 0.00190 \\
\hline \multirow{2}{*}{ HeavyMnfc } & IC-IRTS & -0.03978 & 0.10947 & 0.02364 & 0.02964 & 0.00751 & -0.04771 & 0.01011 & 0.02310 & 0.01879 & 0.00538 & 0.01001 & 0.00449 \\
\hline & PC-CRTS & -0.00425 & -0.01621 & -0.01464 & -0.01112 & -0.02829 & 0.00141 & -0.00846 & -0.00106 & -0.00809 & -0.03287 & -0.00494 & 0.00210 \\
\hline \multirow[t]{2}{*}{ Util_Cons } & IC-IRTS & 0.00039 & -0.00403 & 0.00025 & 0.00051 & 0.00126 & 0.00019 & 0.00164 & 0.00002 & 0.00270 & 0.00193 & 0.00257 & 0.00016 \\
\hline & PC-CRTS & 0.00125 & -0.00280 & 0.00190 & 0.00328 & 0.00577 & 0.00056 & 0.00205 & 0.00134 & 0.00199 & 0.00757 & 0.00163 & -0.00040 \\
\hline \multirow{2}{*}{ Airtransp } & IC-IRTS & -0.00864 & 0.03598 & -0.00020 & 0.00524 & -0.00084 & -0.00744 & -0.00102 & 0.00169 & 0.00320 & 0.00076 & 0.00223 & 0.00032 \\
\hline & PC-CRTS & -0.00261 & 0.04844 & -0.00601 & -0.01582 & -0.01381 & -0.00002 & -0.00687 & -0.00215 & -0.00253 & -0.00321 & -0.00552 & 0.00166 \\
\hline \multirow{2}{*}{ Seatransp } & IC-IRTS & 0.18282 & 0.02414 & 0.04718 & 0.03583 & 0.01471 & 0.00470 & 0.00936 & 0.02172 & -0.00280 & 0.03734 & 0.01025 & -0.00402 \\
\hline & PC-CRTS & 0.12381 & 0.53733 & 1.72818 & 1.12269 & 0.72542 & -0.04448 & 0.30064 & 0.88400 & 0.24775 & 1.44211 & 0.35115 & -0.15584 \\
\hline \multirow[t]{2}{*}{ Otherstransp } & IC-IRTS & -0.00294 & 0.00433 & 0.00085 & 0.00459 & -0.00042 & -0.00370 & 0.00029 & 0.00298 & 0.00133 & 0.00090 & -0.00090 & 0.00032 \\
\hline & PC-CRTS & 0.00070 & 0.00009 & 0.00000 & -0.00400 & 0.00787 & 0.00148 & 0.00217 & 0.00726 & 0.00762 & -0.01506 & -0.00039 & -0.00111 \\
\hline \multirow[t]{2}{*}{ Trade } & IC-IRTS & 0.00448 & 0.02050 & 0.00232 & 0.00066 & -0.00095 & -0.00253 & 0.00006 & 0.00029 & 0.00146 & -0.00027 & -0.00085 & 0.00003 \\
\hline & PC-CRTS & 0.00171 & -0.00500 & -0.00271 & -0.00265 & -0.00815 & 0.00050 & -0.00113 & -0.00284 & 0.00005 & -0.00467 & 0.00067 & 0.00017 \\
\hline \multirow[t]{2}{*}{ Communicat } & IC-IRTS & -0.00617 & 0.00153 & -0.00071 & 0.00080 & -0.00523 & -0.00038 & 0.00015 & -0.00026 & 0.00156 & 0.00030 & 0.00165 & 0.00018 \\
\hline & PC-CRTS & -0.00078 & 0.04358 & -0.00263 & -0.00481 & -0.02350 & -0.00055 & 0.00046 & -0.00248 & 0.00047 & -0.00644 & -0.00327 & 0.00035 \\
\hline \multirow[t]{2}{*}{ FinlnBis } & IC-IRTS & -0.00647 & -0.00843 & -0.00229 & -0.00174 & -0.00612 & 0.00261 & -0.00002 & -0.00081 & 0.00131 & 0.00034 & 0.00160 & 0.00013 \\
\hline & PC-CRTS & -0.00149 & 0.00785 & -0.00184 & -0.00724 & -0.01600 & 0.00093 & 0.00129 & 0.00003 & 0.00044 & -0.00658 & -0.01025 & 0.00039 \\
\hline \multirow[t]{2}{*}{ Tourism } & IC-IRTS & -0.00343 & -0.00113 & 0.00073 & -0.00347 & -0.00208 & 0.00274 & 0.00033 & -0.00129 & 0.00337 & 0.00029 & -0.00035 & 0.00024 \\
\hline & PC-CRTS & -0.00105 & -0.00574 & -0.00130 & -0.00621 & -0.00856 & 0.00023 & -0.00100 & -0.00179 & -0.00185 & -0.01284 & -0.00789 & 0.00017 \\
\hline \multirow[t]{2}{*}{ OthServices } & IC-IRTS & -0.00047 & 0.00582 & 0.00073 & 0.00117 & -0.00084 & 0.00499 & 0.00086 & 0.00210 & 0.00326 & 0.00056 & 0.00014 & 0.00021 \\
\hline & PC-CRTS & 0.00000 & -0.00399 & 0.00075 & -0.00207 & -0.00968 & 0.00013 & -0.00144 & -0.00452 & -0.00113 & -0.00224 & -0.00026 & -0.00001 \\
\hline
\end{tabular}


Trade Barrier Elimination, Economics of Scale, and...

Widyastutik, Suahasil Nazara, Rina Oktaviani, Djamester Simarmata

Appendix 2. Regional Aggregation

\begin{tabular}{clll}
\hline No & Code & Comprising & Regional Aggregation \\
\hline I & IDN & Indonesia & Indonesia \\
2 & MYS & Malaysia & Malaysia \\
3 & PHL & Philippines & Philippines \\
4 & THA & Thailand & Thailand \\
5 & SGP & Singapore & Singapura \\
6 & CHN & China & China \\
7 & JPN & Japan & Japan \\
8 & KOR & Korea & Korea \\
9 & AUS & Australia & Australia \\
I0 & NZL & New Zealand & New Zealand \\
II & IND & India & India \\
I2 & ROW & Rest of the world & Regional except I until I2 \\
\hline
\end{tabular}

\section{Appendix 3. Sectoral Aggregation}

\begin{tabular}{|c|c|c|c|}
\hline No & Code & Comprising & Sectoral Aggregation \\
\hline 1 & Agriculture & $\begin{array}{l}\text { Tanaman Pangan, Hortikultura, } \\
\text { Peternakan } \\
\text { Kehutanan, Perikanan }\end{array}$ & $\begin{array}{l}\text { Pdr; wht; gro; vff; osd; c_b; pbf; ocr; } \\
\text { pcr ; ctl; oap; rmk; wol; cmt; omt; Frs; } \\
\text { Fsh }\end{array}$ \\
\hline 2 & Mng & Pertambangan & Coa; oil; gas; omn \\
\hline 3 & Profood & Makanan Olahan & Vol; mil; sgr; ofd; b_t \\
\hline 4 & TexWapp & Tekstil dan Produk Tekstil & Tex; wap \\
\hline 5 & LightMncf & ManufakturI & Lea; lum; ppp; fmp;muh;otn; omf \\
\hline 6 & HeavyMnfc & Manufaktur2 & P_c; crp; nmm; I_s; nfm; ele;ome \\
\hline 7 & Util_Cons & Listrik, gas, air dan konstruksi & Elyk gdt; wtr; cns \\
\hline 8 & AirTransp & Transportasi Udara & Atp \\
\hline 9 & SeaTransp & Transportasi Laut & Wtp \\
\hline 10 & OthersTrans & Transportasi lainnya & Otp \\
\hline II & $\mathrm{Cmn}$ & Komunikasi & $\mathrm{Cmn}$ \\
\hline 12 & Trd & Distribusi & Trd \\
\hline 13 & FinlnBis & Keuangan dan Bisnis & Ofi; isr; obs \\
\hline 14 & Tourism & Pariwisata & Ros \\
\hline 15 & OtherSrvs & Jasa Lainnya & Osg; dwe \\
\hline
\end{tabular}

